\title{
THE INFLUENCE OF ONLINE AND OFFLINE STRATEGIC MARKETING COMMUNICATION TO PURCHASE INTENTION OF SINGAPORE AIRLINES
}

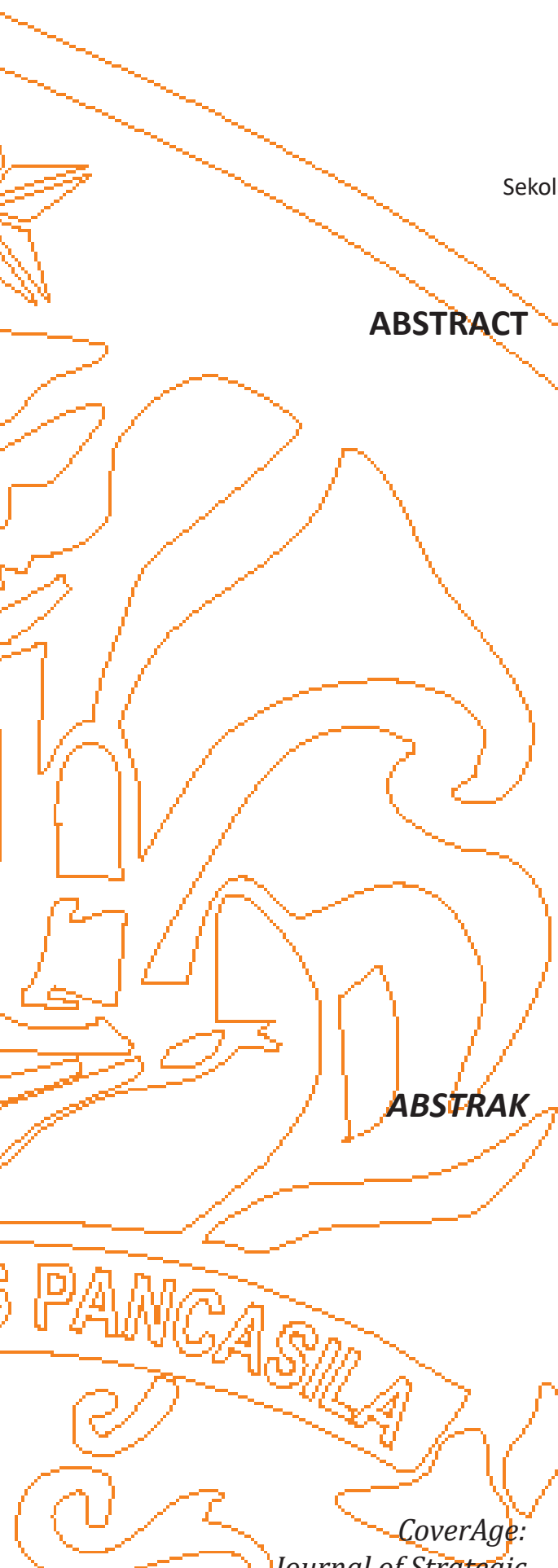

Journal of Strategic

Communication

Vol. 9, No. 2, Hal. 1-10.

Maret 2019

Fakultas Ilmu Komunikasi Universitas Pancasila

Accepted December 16, 2018 Approved February 4, 2019

\author{
PRATIWI MULYANTINA
}

ekolah Tinggi Ilmu Komunikasi London School of Public Relations Email: pratiwi.mulyantina@gmail.com

The purpose of this thesis is to find out which of Singapore Airline to promote Premium Economy Class, both online and offline marketing communication channels, has greater impact to increase its Product Awareness and come out with Marketing Strategies purchase decision. This study uses quantitative method by finding out the influence of online and offline Strategic Marketing Communication by Singapore Airlines Premium Economy Class in Purchase Intention followed by post-positivist paradigm and mix method. As the result, the researcher uses 100 correspondences who are Indonesian passengers living in Jakarta and usually travel on Singapore Airlines and registered as Singapore Airlines members. The research result shows that (1) Brand Awareness in online marketing strategies has a greater influence on Purchase Intention at $41.2 \%$ while Brand Awareness in the offline marketing strategies has an influence of $33 \%,(2)$ brand knowledge on online marketing strategies has a greater influence on Purchase Intention at $48.1 \%$ while Brand knowledge in offline marketing strategies has an influence of $15.7 \%$, (3) Brand likeness in online marketing strategies has a greater influence on Purchase Intention at $47.3 \%$ while Brand likeness in offline marketing strategies has an influence of $20.7 \%$, (4) Brand preference on online marketing strategies has a greater influence on Purchase Intention at $52.1 \%$ while Brand preference on offline marketing strategies has an influence of $24.9 \%$, (5) brand conviction on online marketing strategies has a greater influence on Purchase Intention at $54 \%$ while brand conviction in offline marketing strategies has an influence of $26.6 \%$

Keywords: Premium economy class, marketing strategies, purchase intention.

Tujuan dari tesis ini addlah untuk mengetahui Strategi Pemasaran Maskapai Singapura Airline Kelas Ekonomi Premium, baik saluran komunikasi pemasaran online dan offline, yang memiliki dampak lebih besar untuk meningkatkan kesadaran produk dan menghasilkan keputusan pembelian. Penelitian ini menggunakan metode kuantitatif dengan mencari tahu pengaruh komunikasi pemasaran strategis online dan offline oleh kelas ekonomi premium Singapore Airlines dalam Intensi. Sebagai hasilnya, peneliti menggunakan 100 korespondensi yang merupakan penumpang Indonesia yang tinggal di Jakarta dan biasanya bepergian dengan Singapore Airlines dan terdaftar sebagai anggota Singapore Airlines. Hasil penelitian menunjukkan bahwa (1) Kesadaran Merek dalam strategi pemasaran online memiliki pengaruh lebih besar pada purchase intention di 41,2\% sedangkan Kesadaran Merek dalam strategi pemasaran offline memiliki pengaruh 33\%, (2) Pengetahuan merek pada strategi pemasaran online memiliki pengaruh yang lebih besar pada intensi pembelian pada $48,1 \%$ sementara pengetahuan Merek dalam strategi pemasaran offline memiliki pengaruh 15,7\%, (3) Keserupaan merek dalam strategi pemasaran online memiliki pengaruh yang lebih besar pada Intensi pembelian sebesar 47,3\% sedangkan keserupaan merek dalam strategi pemasaran offline memiliki pengaruh 20,7\%, (4) Preferensi merek pada strategi pemasaran online memiliki pengaruh lebih besar pada purchase intention sebesar 52,1\% sedangkan preferensi merek pada strategi pemasaran offline memiliki pengaruh 24,9\%, (5) Keyakinan merek terhadap strategi pemasaran online memiliki pengaruh lebih besar pengaruh pada Intensi Pembelian sebesar 54\% sementara keyakinan merek dalam strategi pemasaran offline memiliki pengaruh $26,6 \%$

Kata Kunci: Kelas ekonomi premium, strategi pemasaran, intensi pembelian. 


\section{INTRODUCTION}

Kuo and Rong (2017, p.134) gives an explanation on Premium Economy Class which is generally offered on a rate slightly more expensive than regular economic lass but below business class. It offers several facilities such as priority check-in, boarding, and baggage handling. Last but not least the seat selection offered by the premium economy class allows passengers to do business activities or to rest during the trip (Kuo and Rong, 2017, p.134).

Besides Indonesia, Singapore and Philippines, Premium Economy Class is also launched in some other countries, such as Los Angeles trough events for travel agents, tourism board and airport officials. More than 170 guests were present at The London Hotel, taking the opportunity to try out the seats assisted by two cabin crews and to taste the various meal options offered under Premium Economy Book-the-cook. Special fares to Singapore and Tokyo offered and a draw was held for two Premium Economy Class tickets to Tokyo. In Los Angeles, Premium Economy Classes also promoted at 'Japan Family Day'. Attracting over 1,000 visitors, this annual event doubles as a 'Japan Family Day' with a variety of activities held by the race track such as tea ceremony, flower arrangement, calligraphy, origami and Japanese Anime as well as Sumo Wrestling. Singapore Airline promotes various tour packages to Japan and highlight the New Premium Economy Class product scheduled on Los Angeles - Tokyo route.

The Company's News Bulletin in November 2015 states that the Premium Economy Class launch was a success with "more-than-encouraging" load factors and forward bookings. The Product has already won two major awards. Singapore Airline's exposure on social media is growing with greater use of these platforms to engage young travelers. Its social media community is now followed by encouraging four-million users with two million of them on facebook.

\section{LITERATURE REVIEWS}

There have been several studies examining the influence of online marketing and offline marketing on purchasing decisions. The influence of online marketing on purchasing decisions is comprehensively discussed by Putter (2017), Pradana and Eka (2015), lik and Agus (2018), and Sutanto and Atik (2016). They suggested that online marketing has a significant impact on Purchasing Decisions both simultaneously and partially. More specifically, Sulistyo and Sudaryanto (2015), Mileva and Achmad (2018) and Susilowati, et al. (2019) suggest that social media such as Twitter, Line and Facebook are able to significantly improve consumer purchasing decisions.

The study of Gao (2019) shows that offline marketing through increased brand awareness has a significant impact on increasing purchasing decisions on several airlines such as Singapore Airlines, Emirates and Air Asia, unlike the study of Seo and Jin (2018) which explains that social media marketing (online marketing) can improve purchasing decisions in the airline industry. A different approach is taken by Yalanda and Agriani (2019) that suggests that both online and offline marketing can boost up product purchasing decisions.

\section{Marketing Communication}

According to Belch and Belch (2009 p.16), marketing communication is a concept to communicate various marketing strategies such as promotion, direct marketing, personal selling, advertising and others. Building Brands is the overall objective of all marketing communication as well as all marketing activities (Duncan, 2008, p. 45).

Marketing Communication consist of the messages companies send and receive and the media involved. It's also about the perceptions, how customers interpret the many messages they receive about a brand. While a Marketing Communication Mix is the selection of Marketing Communication functions used at a given time as part of a marketing program (Duncan, 2008, p. 45).

According to Tjiptono (2008, p. 219), marketing communication is an activity that seeks to spread information, influence / persuade and / or remind target markets for companies and their products to be willing to accept, buy and be loyal to the products offered by the company.

Marketing and communication are closely related. Communication is the process of passing symbols interpreted equally between individuals to individuals, individuals to groups, groups to groups and groups to the masses. Communication in marketing activities is complex, meaning that it is not as simple as talking with colleagues at work, or with family at home. More complicated forms of communication 
encourage communicators to convey messages to the communicant through a sophisticated communication strategy, after going through a careful planning process (Soemanegara, 2006, p. 1-3).

Marketing communication is a means by which companies try to inform, persuade, and remind customers directly or indirectly about the products and brands it is selling. Marketing communication also carries out many functions for customers. Marketing communication can tell or show customers about how and why, by whom and where and when the product is used. Marketing communication allows companies to connect their brands with people, places, events, brands, experiences, feelings and other things. It can contribute to brand equity, by embedding brands in the memories of customers thus creating image, as well as driving sales, and even affecting the value of shares (Kotler and Keller, 2009, p.172).

\section{Online Marketing}

The rapid growth of the internet-the digital revolution-has led to changes in the marketing environment forcing marketers to rethink almost everything they do. As the World Wide Web evolves, so does marketing communication programs. The ability to target customers effectively through the Net is an incentive for marketers. The increased attention for accountability on the part of business has led to a view of the internet as a medium that would provide more direct feedback on the value of marketing expenditures, customer satisfaction, trends, and the competition (Belch, 2012, p.490).

Unlike traditional Media, it is often easier to account for the ROI of their expenditures. Other factors contributing to marketers' increased attention on the Internet include the increasingly fast Internet connections prompting users to spend more time online and increased use of social media attracting attention and involvement and new ways to advertise, technologies that allow the tracking of customers' interest and purchase behaviors as well as increased ability to reach more potential buyers (Belch, 2012, p. 491).

Based on (Belch, 2012, p.495) Internet is actually a kind of media and website is a communication medium, allowing companies to:

a. Create awareness. Namely to provide information and influence attitudes and to fulfill other communications objectives. b. Generate Interest. Namely to create interest that will prompt visitors to access the Brand's website to learn more about the product and to sell products.

c. Disseminate Information. One of the primary objectives of Web is to provide in-depth information about a company's products and services. In Business-to-Business markets, having a website has become a necessity as more buyers expect companies to have a website to obtain detailed information about their products.

d. Create an Image. Many websites are designed to reflect the image a company wants to portray.

e. Create a strong Brand. The Internet as part of an integrated marketing communication program can be a useful tool for Branding.

f. Create Buzz. One of the many advantages of the Web is the ability to create buzz. The nature of social networking and other sites make them attractive to marketers intending to spread the words.

g. Gain Consideration. Many marketers believe that the Internet is effective for achieving communications objectives such as consideration and/or evaluation in the forms of blogs and discussion boards which are useful in evaluating products and brands.

Internet marketing also refers to the placement of media along various stages of the customer engagement cycle through search engine marketing (SEM) (Hermawan, 2012, p. 206). According to Monle and Johnson (2011, p. 30) there are various online advertising media namely:

1. online social network. online social networks or social media networks have been very popular among the people and companies looking for communication media with other people or customers. Based on Forrester's research, 75\% of internet users use several types of social media. The growing percentage of customers on the internet lies on social networks or blogs. Below are the social networks widely used by customers:

a. Facebook. It is the largest social media, with a total of more than $310,000,000$ users around the globe with the largest source of advertising compared to other social networks at $14.7 \%$.

b. Twitter. It is a mini blog that allows individuals and companies to send tweets, 
with a maximum of 140 characters per message. Twitter can be an effective method for getting customers.

c. Website. Website advertising is more complex than other types of online advertising. Individuals must choose themselves to visit the web they want, so that the probability of attention of those who choose to visit the web is 1.00

2. Internet and advertising. Back to October 27, 1994 when HotWired was launched through online media, namely the web, Hotwired blew up online advertising since the start of cable television. This makes marketers strive to make their webs advertising tools in addition to magazines, television and radio (Monle and Johnson, 2011, p. 31).

\section{METHOD}

\section{Research Design and Method}

This study uses quantitative method by finding out the influence of online and offline Strategic Marketing Communication by Singapore Airlines Premium Economy Class in Purchase Intention followed by post-positivist paradigm and mix method. Mukhtar (2013, pp.15-16) suggests that paradigm is absolutely needed by a researcher to direct him in determining the types and methods of research, according to the angle of issue.

The strategies of inquiry for mix method are sequential, concurrent, and transformative strategies. Mix method procedures involve open-ended and close-ended question as well as multiple forms of data collection from all possibilities with regard to statistical and text analysis (Creswell 2003 p. 20).

\section{Sampling, Respondents and Resources Persons.}

Population is a combination of all elements in the forms of events, things, or people who have similar characteristics that are the center of attention of researchers, therefore seen as the population of the research (Sugiyono, 2012 p.45). The population in this study is Indonesian passengers living in Jakarta usually traveling on Singapore Airlines and registered as Singapore Airlines members.

The sample is a subset of the population, consisting of several members of the population
(Sugiyono, 2012 p.46). Malhotra (2010 p.35) believe that the sampling for unknown respondent could be done by using non-probability sampling. No researcher knows the exact number of people who have watched the movie Spectre. Non-probability sampling helps the researcher to determine the respondent by using the right criteria. Nonprobability sampling then lead to the convenience sampling by using those criteria as the main way to selected the right sampling to look for the right respondents.

Singapore airlines has more than thousands flyers living in Indonesia, while researcher will only focus on them who live in Jakarta. As the result, the researcher uses Non Probability Sampling (purposive) with 100 correspondences who are Indonesian passengers living in Jakarta and usually travel on Singapore Airlines and registered as Singapore Airlines members.

\section{Data Analysis Procedures}

Data analysis aims to convey and limit the findings to become orderly, organized and more meaningful data. The data analysis performed was quantitative analysis expressed by the numbers and calculations using a standardized method assisted with the Statistical Package Social Sciences (SPSS) version $\mathbf{2 4 . 0 0}$ for windows. The data analysis used in this study was simple linear regression analysis. Before carrying out linear regression analysis, it was first tested with the classical assumption test to ascertain whether the regression model used does not have issues of normality, multicollinearity, and autocolleration. If it is fulfilled then the analysis model can be used

\section{FINDINGS AND DISCUSSION}

This study aims to analyze the comparison of online and offline marketing strategies against the decision to purchase Premium Economy Class. Based on the process of determining the samples of the research questionnaire, has been obtained data from 116 respondents with the questionnaire distribution process as follows. 
Table 1.

Questionnaire Distribution Process

\begin{tabular}{|c|c|}
\hline Process & Total \\
\hline Questionnaire distributed & 116 \\
\hline Questionnaire returned & 116 \\
\hline $\begin{array}{c}\text { Respondents never using Premium } \\
\text { Economy Class }\end{array}$ & $(9)$ \\
\hline Questionnaire ready for analysis & 107 \\
\hline
\end{tabular}

Source : the Researcher

\section{Result of Classic Assumption Test.}

\section{Online Marketing Classic Assumption Test Result}

a. Data Normality Test Result

Normality test aims to test whether or not in the regression model, the dependent variable and the independent variable both have normal distribution (Ghozali, 2013 p.60). If the data distribution is normal or close to normal, the regression model is good. Below is the result of the data normality test.

Figure 1.

\section{Data Normality Result Test}

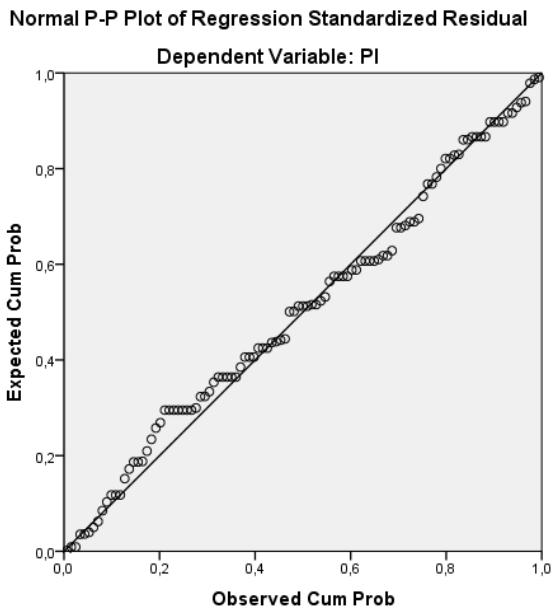

Based on Figure 4.1, it is known that the data is normally distributed as the points spread around the diagonal line and the distribution follows the direction of the diagonal line (Ghozali, 2013 p.60).

b. Data Multicollinearity Test Result

Multicollinearity Test aims to test whether regression model has a correlation between independent variables. In a good regression model there should be no correlation between independent variables.

The cut off value commonly used is (Ghozali, 2013 p.61):
1. If the tolerance value is $>10$ percent and the VIF value is $<10$, it can be concluded that there is no multicollinearity between the independent variables in the regression model.

2. If the tolerance value is $<10$ percent and the VIF value is $>10$, it can be concluded that there is multicollinearity between independent variables in the regression model. The multicollinearity test result is as follows.

Table 2.

Result of Data Multicollinearity Test

\begin{tabular}{|c|c|c|c|}
\hline Variable & Tolerance & VIF & Conclusion \\
\hline Brand Awareness & 0.297 & 4.262 & $\begin{array}{c}\text { No multico- } \\
\text { linearity }\end{array}$ \\
\hline Brand Knowledge & 0.182 & 5.144 & $\begin{array}{c}\text { No multico- } \\
\text { linearity }\end{array}$ \\
\hline Brand Likeness & 0.186 & 5.378 & $\begin{array}{c}\text { No multico- } \\
\text { linearity }\end{array}$ \\
\hline Brand Preference & 0.455 & 2.198 & $\begin{array}{c}\text { No multico- } \\
\text { linearity }\end{array}$ \\
\hline Brand Conviction & 0.786 & 1.272 & $\begin{array}{c}\text { No multico- } \\
\text { linearity }\end{array}$ \\
\hline
\end{tabular}

Source: SPSS 24 Output, data processed

The table above shows that the VIF value for Brand Awareness, Brand Knowledge, Brand Likeness, Brand Preference, and Brand Conviction variables is smaller than 10 while the tolerance value is greater than 0.10 (Ghozali, 2013 p.61). This shows that the independent variables in this study do not correlate with each other or there is no correlation between the independent variables meaning the model contains no multicollinearity.

c. Data Autocorrelation Test Result

Autocorrelation test aims to test whether the linear regression model has a correlation between the interrupting error in t period and interrupting error in t-1 period (before) (Ghozali, 2013 p.62). The presence or absence of autocorrelation symptoms can be detected by Durbin-Waston test (DW test). Below is the result of the Autocorrelation test.

Table 3.

\section{Data Autocorrelation Test Result}

\begin{tabular}{|c|c|c|c|c|c|}
\hline \multicolumn{5}{|c|}{ Change Statistics } & \multirow[b]{2}{*}{$\begin{array}{l}\text { Durbin- } \\
\text { Watson }\end{array}$} \\
\hline $\begin{array}{c}\text { R Square } \\
\text { Change }\end{array}$ & F Change & df1 & df2 & $\begin{array}{c}\text { Sig. F } \\
\text { Change }\end{array}$ & \\
\hline, 518 & 14,519 & 5 & 101 &, 000 & 1,811 \\
\hline
\end{tabular}

Source: SPSS 24 Output, data processed 
Autocorrelation test is done by observing the Durbin Watson statistical table. The values of $d u$ and $\mathrm{dL}$ can be seen from table $k=5$ at $n=107$. The value of $d l$ is 1.588 and the value of $d u$ is 1.783 . Based on the formula above, the result of $4-d u$ is 2,217 , while the result of $4-\mathrm{dl}$ is 2,412 . The table above shows that in this study there is no autocorrelation between independent variables as the DW value is 1,811 and falls under autocorrelation free area at du $<\mathrm{d}<4-\mathrm{du}$ $(1,783<1,811<2,217)$. In conclusion, Ho is rejected but $\mathrm{Ha}$ is accepted.

\section{Offline Marketing Classic Assumption Test Result}

a. Data Normality Test Result

Normality test aims to test whether or not in the regression model, the dependent variable and the independent variable both have normal distribution (Ghozali, 2013 p.60). If the data distribution is normal or close to normal, the regression model is good. Below is the result of the data normality test.

Figure 2.

Data Normality Test Result

Normal P.P Plot of Regression Standardized Residual

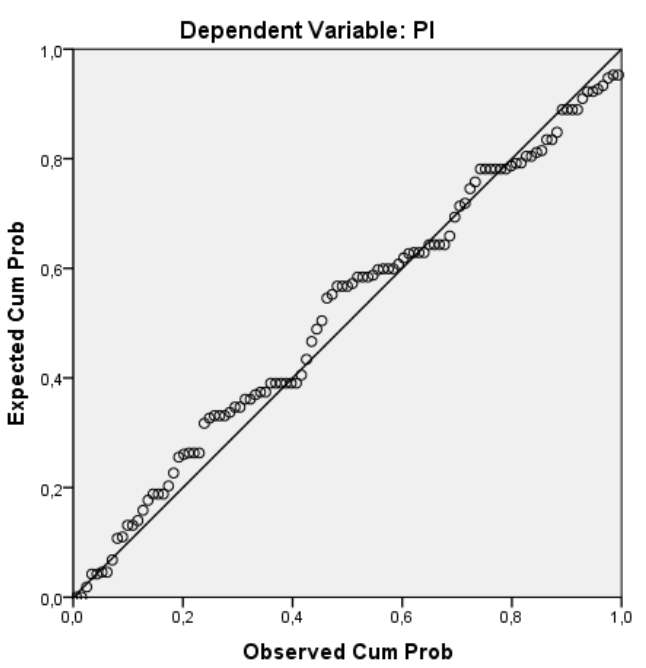

Source: SPSS 24 Output, data processed

Based on Figure 2, it is known that the data is normally distributed as the points spread around the diagonal line and the distribution follows the direction of the diagonal line (Ghozali, 2013 p.60).

b. Data Multicollinearity Test Result

Multicollinearity Test aims to test whether regression model has a correlation between independent variables. In a good regression model there should be no correlation between independent variables. The cut off value commonly used is (Ghozali, 2013 p.61):

1. If the tolerance value is $>10$ percent and the VIF value is $<10$, it can be concluded that there is no multicollinearity between the independent variables in the regression model.

2. If the tolerance value is $<10$ percent and the VIF value is $>10$, it can be concluded that there is multicollinearity between independent variables in the regression model. The multicollinearity test result is as follows.

Table 4.

Data Multicolinearity Test Result

\begin{tabular}{|c|c|c|c|}
\hline Variabel & Tolerance & VIF & Kesimpulan \\
\hline Brand Awareness & 0.115 & 8.721 & $\begin{array}{c}\text { No } \\
\text { multicolinearity }\end{array}$ \\
\hline Brand Knowledge & 0.172 & 5.819 & $\begin{array}{c}\text { No } \\
\text { multicolinearity }\end{array}$ \\
\hline Brand Likeness & 0.188 & 5.328 & $\begin{array}{c}\text { No } \\
\text { multicoliearity }\end{array}$ \\
\hline Brand Conviction & 0.483 & 2.069 & $\begin{array}{c}\text { No } \\
\text { multicolinearity }\end{array}$ \\
\hline
\end{tabular}

Source: SPSS 24 Output, data processed

The table above shows that the VIF value for Brand Awareness, Brand Knowledge, Brand Likeness, Brand Preference, and Brand Conviction variables is smaller than 10 while the tolerance value is greater than 0.10 (Ghozali, 2013 p.61). This shows that the independent variables in this study do not correlate with each other or there is no correlation between the independent variables meaning the model contains no multicolinearity.

c. Data Autocorrelation Test Result

Autocorrelation test aims to test whether the linear regression model has a correlation between the interrupting error in $t$ period and interrupting error in $\mathrm{t}-1$ period (before) (Ghozali, 2013 p.62). The presence or absence of autocorrelation symptoms can be detected by Durbin-Waston test (DW test). Below is the result of the Autocorrelation test. 
Table 5.

Data Autocorrelation Test Result

\begin{tabular}{|c|c|c|c|c|c|}
\hline \multicolumn{5}{|c|}{ Change Statistics } & \multirow[b]{2}{*}{$\begin{array}{l}\text { Durbin- } \\
\text { Watson }\end{array}$} \\
\hline $\begin{array}{c}\text { R Square } \\
\text { Change }\end{array}$ & F Change & df1 & df 2 & $\begin{array}{l}\text { Sig. F } \\
\text { Change }\end{array}$ & \\
\hline 354 & 11,068 & 5 & 101 & 000 & 1,882 \\
\hline
\end{tabular}

Source: SPSS 24 Output, data processed

Autocorrelation test is done by observing the Durbin Watson statistical table. The values of $\mathrm{du}$ and $\mathrm{dL}$ can be seen from table $\mathrm{k}=5$ at $\mathrm{n}=$ 107. The value of $\mathrm{dl}$ is 1.588 and the value of $\mathrm{du}$ is 1.783 . Based on the formula above, the result of $4-\mathrm{du}$ is 2,217 , while the result of $4-\mathrm{dl}$ is 2,412 . The table above shows that in this study there is no autocorrelation between independent variables as the DW value is 1,811 and falls under autocorrelation free area at du $<\mathrm{d}<4$-du $(1,783<1,811<2,217)$. In conclusion, $\mathrm{Ho}$ is rejected but $\mathrm{Ha}$ is accepted.

\section{Hypothetical Test Result}

\section{Influence of Brand Preference on Purchase Intention}

The research result shows that Brand Awareness in online marketing strategies has a greater influence on Purchase Intention at $41.2 \%$ while Brand Awareness in the offline marketing strategies has an influence of $33 \%$. Basically, brand is becoming increasingly important for a company in almost all industries. One way to measure marketing effectiveness as measured by the ability of potential buyers or in this case potential customers to recognize and remember a brand is called brand preference (Kotler and Armstrong, 2013 p.69). Today's customers rely heavily on social media and social networks when making decisions in buying certain brands (Hinz et al., 2011 p. 2). Customers' habit to spend more time on social media has made encouraged communication in social network. At present, social media is a very promising target of marketing communication which can be a promising opportunity for marketers to boost up brand awareness through social media communication. The study of Hutter and Hautz (2013 p.11) shows that engagement with social media has positive impacts on customers' brand awareness. Based on qualitative analysis, it is known that the offline marketing strategies adopted by Singapore Airlines through road shows in malls, offline advertising (newspaper / magazine) and friend's recommendations and online marketing strategies such as Website and online magazines, social media (facebook and instagram).

\section{Influence of Brand Knowledge on Purchase Intention}

The research result shows that brand knowledge on online marketing strategies has a greater influence on Purchase Intention at $48.1 \%$ while Brand knowledge in offline marketing strategies has an influence of $15.7 \%$. According to Kotler and Keller (2007 p.243) Brand knowledge is conceptualized as a memory of various associations about a brand. According to Ruslim and Andrew (2012: 36), Brand Conviction is a collection of all accurate information stored in a customer's memory which is as good as his perception of product knowledge. A consumer seeks information about a brand to add information about the brand to be purchased and to add more information already known by him so that the customer's knowledge about the brand will increase. Through the use of social media, a brand can be more easily communicated along with the benefits that potential customers will get in real time using smartphones. Therefore, online marketing strategies can communicate a brand or product more effectively and efficiently.

\section{Influence of Brand Likeness on Purchase Intention}

The research result shows that Brand likeness in online marketing strategies has a greater influence on Purchase Intention at $47.3 \%$ while Brand likeness in offline marketing strategies has an influence of $20.7 \%$. According to Durianto (2011 p.59) brand likeness means customers belonging to the category of liking of the brand category namely customers who really like the brand. This level involves emotional feelings with regard to the brand. Customer liking can be based on associations with symbols, a series of experiences in previous use experienced personally and or by relatives or even caused by high perceived quality. Through optimization of online strategies, customers will have better emotional ties through the frequency of marketing communications continually updated through social media. In addition, with attractive and creative ad designs, online marketing strategies can be more easily liked by customers.

\section{Influence of Brand Preference on Purchase Intention}

The research result shows that Brand preference on online marketing strategies has a greater influence on Purchase Intention 
at $52.1 \%$ while Brand preference on offline marketing strategies has an influence of $24.9 \%$. Any purchase decision made by a customer in buying a product is always influenced by various factors. One factor that influences purchasing decision is brand preference (Ardhanari, 2008 p.32). Brand preference is a relative preference for selecting and using a certain brand over other brands. Chomvilailuk, et al (2010 p.15) defines brand preference as anything based on which a customer prefers a brand of a product based on his first experience in using that brand compared to other similar brands. Through online strategy optimization, customers can continue to get information about the latest features and innovations of a brand to easily compare it with products of other brands. Based on qualitative analysis, recommendations from travel bloggers are able to increase the Brand preference ction in the Premium Economy Class thereby increasing passengers' Purchase Intention.

\section{Influence of Brand Conviction on Purchase Intention}

The research result shows that brand conviction on online marketing strategies has a greater influence on Purchase Intention at $54 \%$ while brand conviction in offline marketing strategies has an influence of $26.6 \%$. With regard to brand conviction, at this stage the brand is more than desirable, but the customer does not yet have enough confidence to use the product so that the communicator has the duty to convince the customer that using the offered brand is the right thing to do. In this case, the role of electronic word of mouth can be beneficial through discussions on social media forums or through recommendations from customers who have used the product through testimonials posted on the company's website. Based on qualitative analysis, recommendations from travel bloggers are able to increase the Brand Conviction in the Premium Economy Class thereby increasing passengers' Purchase Intention.

\section{CONCLUSIONS}

Based on the results of the study, below are the conclusions of this study:

1. Based on the results of the distribution of questionnaires, offline marketing can contribute to Premium Economy Class marketing communication through: Events or Road Shows in malls, offline advertising (print media), and mouth-to- mouth Recommendation. Whereas online marketing can contribute to Premium Economy Class marketing communication through: Online websites and magazines, social media (Facebook and Instagram), and recommendations from travel blogs

2. The result of the study indicates that Brand Awareness on online marketing strategies has a greater influence on Purchase Intention compared to offline marketing. Consumer tend to spend more time on social mediathus boosting the communication on the social networking environment which can be a promising opportunity for marketers to increase brand awareness through social media communication.

3. The result of the study indicates that Brand Knowledge on online marketing strategies has a greater influence on Purchase Intention than offline marketing. Through the use of social media, a brand can be more easily communicated along with the benefits that potential customers will get in real time using their smart phones.

4. The result of the study shows that Brand Likeness on online marketing strategies has a greater influence on Purchase Intention than offline marketing. Through optimization of online strategies, customers will have better emotional ties through the frequency of marketing communications that can always be updated through social media. In addition, with attractive and creative ad designs, online marketing strategies will likely be preferred by customers

5. The result of the study shows that brand preference on online marketing strategies has a greater influence on Purchase Intention than offline marketing. Through online strategy optimization, customers can continue to get information about the latest features and innovations of a brand so that customers can more easily compare it with other brands

6. The results of the study indicates that Brand conviction on online marketing strategies has a greater influence on Purchase Intention than offline marketing. Here the role of electronic word of mouth can be done through discussions on social media forums or through recommendations from customers who have used the product 
through testimonials that can be read on the company's website.

\section{Recommendations}

Based on the results of the study, the following are suggestions made in this study:

\section{Academic Recommendation}

For further studies, it is recommended to conduct a comparison with other companies to obtain more comprehensive research results on online and offline marketing strategies in relation to purchase intention.

\section{Practical Recommendation}

1. Based on research results, it is known that online marketing strategies have a greater effect on purchase intention than offline marketing strategies.

2. Therefore, it is recommended for Singapore Airlines to improve its online marketing communication through social media forums such as Facebook and Instagram to increase its Brand Awareness through Brand Conviction of Singapore Airline's Premium Economy Class services.

3. In addition, to enhance the emotional ties of customers with Singapore Airlines, it is recommended for the company to equip the website with 24-hour customer service so that customers can ask questions about services and benefits while being the place to channel complaints and give suggestions from Premium Economy Class customers in real time to continually improve the quality of service according to customers' expectations.

\section{REFERENCES}

Ardhanari, M. (2008). Customer Satisfaction Pengaruhnya Terhadap Brand Preference dan Repurchase Intention Private Brand. Jurnal Riset Ekonomi dan Bisnis, 8(2), 58-68.

Chomvilailuk., R., \& Butcher, K. (2010). Enhancing Brand Preference Through Corporate Social Responsibility Initiatives in the Thai Banking Sector. Asia Facific Journal of Marketing and Logistics, 22(3), 397-418.

Creswell, J. W. (2003). Research Design Qualitative, Quantitative and Mixed Methods Approaches Second Edition. New Delhi: Sage Publications.
Durianto, D. (2011). Strategi Menaklukkan Pasar Melalui Riset Ekuitas dan Perilaku Merek. Jakarta: PT. Gramedia Pustaka Utama.

Gao, Y. (2019). Brand Awareness, Purchase Intention and Price Premium of International Airlines Operating between Australia and the United Kingdom. International Journal of Aviation, Aeronautics, and Aerospace, 6 (3), 1-18.

Ghozali, I. (2013). Aplikasi Analisis Multivariate dengan Program IBM SPSS 21 Update PLS Regresi. Semarang: Badan Penerbit Universitas Diponegoro.

Hermawan, A. (2012). Komunikasi Pemasaran. Jakarta: Erlangga.

Keller, Kevin L. (2003). Strategic Brand Management: Building Measuring, and Managing Brand Equity. New Jersey: Prentice Hall.

Kotler, P., \& Kelle, K.L. (2009). Manajemen Pemasaran, Edisi 13 Jilid satu. Jakarta : Erlangga.

Kotler P., \& Gary, A., (2013). Prinsip-prinsip Pemasaran, Edisi ke-12. Jakarta: Penerbit Erlangga.

Kuo, Chung-Wei., \& Jou, R.C., (2017). Willingness to pay for airlines' Premium Economy Class: The Perspective of Passenger. Journal of Air Transport Management, 59(2), 134-142.

Malhotra, N. K. (2010). Riset Pemasaran (Marketing Research). Jakarta: PT. Indeks.

Mileva, L. \& Fauzi, A., (2018). Pengaruh Social Media Marketing terhadap Keputusan Pembelian (Survei Online pada Mahasiswa Sarjana Jurusan IImu Administrasi Bisnis Angkatan 2014/2015 Fakultas IImu Administrasi Universitas Brawijaya yang Membeli Starbucks Menggunakan LINE). Jurnal Administrasi Bisnis, 58(1), 190-199.

Mukhtar. (2013). Metode Penelitian Deskriftif Kualitatif. Jakarta: GP Press Group.

Putter, M. (2017). The Impact of Social Media on Consumer Buying Intention. Journal of International Business Research and Marketing, 3(1), 7-13.

Ruslim, T. S., \& Andrew, R. (2012). Pengaruh Brand Image dan Product Knowledge terhadap Purchase Intention (Kasus: Kosmetik Merk X). Jurnal Media Bisnis, 2(5), 34-44.

Seo, Eun-Ju., \& Park, J.W. (2018). A study on the effects of social media marketing activities on brand equity and customer response in the airline industry. Journal of Air Transport Management, 66(2), 36-41. 
Singapore Airlines. (2015). Singapore Airlines Unveils New Premium Economy Class Experience. Retrieved from Singaporeair.com/en_UK/us/ media-centre/press-release/article/.

Sugiyono. (2012). Metode Penelitian Bisnis. Bandung : Alfabeta.

Sulistyo, P. B., \& Sudaryanto. (2015). Analisis Pengaruh Viral Marketing Terhadap Pembentukan Brand Awareness dan Keputusan Pembelian (Studi Kasus pada Twitter @Jemberbanget). Artikel IImiah Mahasiswa, 2(5), 1-6.

Susilowati, R., Pangestuti, E., \& Aniesa Samira Bafadhal. (2019). Pengaruh Viral Marketing terhadap Kepercayaan dan Dampaknya pada Keputusan Pembelian. Jurnal Administrasi Bisnis, 66(1), 1-9.

Sutanto, M. A., \& Atik Aprianingsih. (2016). The Effect of Online Consumer Review Toward Purchase Intention: A Study in Premium Cosmetic in Indonesia. International Conference on Ethics of Business, Economics, and Social Science, 218-230.

Tjiptono, F. (2008). Strategi Pemasaran, Edisi III, Yogyakarta : CV. Andi Offset.

Yalanda, R. R., \& Sadeli, A. H. (2019). Pengaruh Direct Marketing Terhadap Keputusan Pembelian Kopi Arabika Malabar Mountain Coffee Studi Kasus pada konsumen PT. Sinar Mayang Lestari. Jurnal Performance, 26(1), 27-38. 